\title{
Metabolism of $\alpha$-Ketoaldehydes in Yeasts: Purification and Characterization of Glyoxalase II from Saccharomyces cerevisiae
}

\author{
Kousaku Murata, Yoshiharu Inoue, Kunihiko Watanabe, \\ Yasuki Fukuda, Toshihiko SaIKuSA, Makoto ShImosaKa \\ and Akira Kimura
}

Research Institute for Food Science, Kyoto University, Uji, Kyoto 611, Japan

Received July 3, 1985

\begin{abstract}
Glyoxalase II, that catalyzes the conversion of S-lactoylglutathione into lactate and glutathione, was isolated from the yeast, Saccharomyces cerevisiae, and some properties of the enzyme were determined. The glyoxalase II was purified approximately 100 fold from a cell extract with a $20 \%$ activity yield. Estimation of the molecular weight of the enzyme by both gel filtration and SDS/polyacrylamide gel electrophoresis gave a value of $1.9 \times 10^{4}$. Among the various thiol esters tested, the enzyme hydrolyzed only $S$-lactoylglutathione with a $\mathrm{Km}=7.0 \times 10^{-6} \mathrm{M}$. The enzyme was most active at low pH (pH $3 \sim 4)$ and was stable even in $0.001 \mathrm{~N} \mathrm{HCl}$ at $40^{\circ} \mathrm{C}$ for at least $15 \mathrm{~min}$. The activity of the enzyme was inhibited by various thiol compounds such as glutathione and coenzyme A. Hemimercaptal, a non-enzymatic condensation product of methylglyoxal and glutathione, strongly inhibited the activity of the enzyme.
\end{abstract}

Methylglyoxal, a toxic compound for yeast proliferation, has been thought to be converted into lactate by sequential enzyme reactions catalyzed by glyoxalase I [EC 4.4.1.5] and glyoxalase II [EC 3.1.2.6] in the presence of glutathione (Eq. 1). Yeast glyoxalase I has been purified from Saccharomyces cerevisiae and its properties were determined by Racker ${ }^{1)}$ and Marmstal et al. ${ }^{2)}$ However, attempts to purify glyoxalase II from yeast cells have not been made so far and, therefore, the physiological significance of glyoxalase II and other thiol esterases in yeast cells remains obscure.

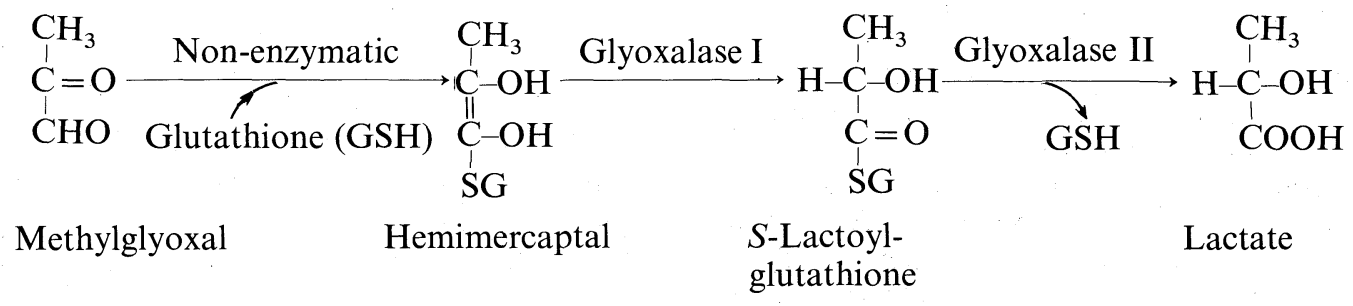

(Eq. 1)

In the present communication, 100 fold purification of yeast glyoxalase II and some of its properties are described in comparison with those of glyoxalase II partially, purified from human liver by Uotila. ${ }^{3)}$.

glutathione

\section{MATERIALS AND METHODS}

Chemicals. S-Lactoylglutathione and the other glutathione thiol esters, except for $S$-acetylglutathione, were from Sigma Chemical Co., St. Loius, Mo, U.S.A. $S$ Acetylglutathione was prepared by the method of Kielley 
and Bradley. ${ }^{4)}$

Cultivation and preparation of a cell extract. Cells of Saccharomyces cerevisiae DKD-5D-H (a leu2 3 leu2 112 trpl his3), which was obtained from Dr. Y. Oshima, were cultured in a medium containing $2.0 \%$ yeast extract, $2.0 \%$ peptone and $2.0 \%$ glucose $(\mathrm{pH} \mathrm{5.0,1.5} \mathrm{liter}$ of medium in a 2 liter Sakaguchi flask) for $24 \mathrm{hr}$ at $30^{\circ} \mathrm{C}$ with reciprocal shaking. The cells ( $98 \mathrm{~g}$ as wet wt.) from 10 liters of culture fluid were washed once with $0.85 \%$ saline solution, resuspended in $10 \mathrm{~mm}$ tris (hydroxymethyl)aminomethane (Tris)-HCl buffer ( $\mathrm{pH}$ 7.3) containing $0.1 \mathrm{~mm}$ phenylmethylsulfonylfluoride (PMSF) [TrisPMSF], and then homogenized in a Dyno-Mill for $3 \mathrm{~min}$ at $0^{\circ} \mathrm{C}$. The homogenate was centrifuged at $25,000 \times g$ for $30 \mathrm{~min}$, and the resultant supernatant was used for the purification of glyoxalase II. Other procedures involved in the cultivation of cells and preparation of cell extracts were described in detail in our previous paper. ${ }^{5}$ Unless otherwise noted, all the purification procedures were performed at $4^{\circ} \mathrm{C}$.

Assay for glyoxalase II. Glyoxalase II activity was assayed by following the decrease in absorbancy at $240 \mathrm{~nm}$ as described by Uotila. ${ }^{2)}$ The reaction was carried out in a mixture $(1.0 \mathrm{ml})$ containing $1.0 \mathrm{~mm} S$-lactoylglutathione, $50 \mathrm{~mm}$ Tris- $\mathrm{HCl}$ buffer ( $\mathrm{pH} 7.3$ ) and an appropriate amout of enzyme at $25^{\circ} \mathrm{C}$, and the decrease in absorbancy at $240 \mathrm{~nm}$ was recorded with a Hitachi Spectrophotometer Model 100-50. At $240 \mathrm{~nm}$, a molar absorption coefficient of $33,000 \mathrm{~cm}^{-1}$ was used for $S$-lactoylglutathione. ${ }^{1)}$ Specific activity was expressed as nmol of $S$ lactoylglutathione hydrolyzed per min per $\mathrm{mg}$ of protein. Protein was determined by the method of Lowry et al. ${ }^{6}$

\section{Purification of glyoxalase II}

(1) DEAE-cellulose column chromatography. The supernatant obtained above $(5,830 \mathrm{mg}$ protein, $370 \mathrm{ml})$ was directly applied to a DEAE-cellulose column $(5.5 \mathrm{~cm} \times 50 \mathrm{~cm})$ equilibrated with Tris-PMSF, followed by elution with a linear gradient of $\mathrm{KCl}(0 \sim 1.0 \mathrm{M}$ in TrisPMSF; total volume, $3,000 \mathrm{ml})$. Fractions were collected at $20 \mathrm{ml} /$ tube $/ 10 \mathrm{~min}$. The active fractions (conductivity, $15 \sim 25 \mathrm{m \mho}$ ) were pooled, and then concentrated to $50 \mathrm{ml}$ by ultrafiltration with an Amicon PM10 membrane.

(2) Sephadex G-150 column chromatography. The active fractions $(2,160 \mathrm{mg}$ protein, $480 \mathrm{ml})$ from the DEAEcellulose column were applied to a Sephadex G-150 column $(4.0 \mathrm{~cm} \times 90 \mathrm{~cm})$ equilibrated with Tris-PMSF, and the enzyme was eluted with Tris-PMSF at a flow rate of $10 \mathrm{ml} /$ tube $/ 15 \mathrm{~min}$. The active fractions (Fr. Nos. $110 \sim 155$ ), which were eluted at $V e / V o=2.4$, were combined and concentrated to $20 \mathrm{ml}$ with an Amicon PM10 membrane. $V e$ and $V o$ are the elution volume of the enzyme and the void volume of the column, respectively.

(3) DEAE-Sepharose CL-6B column chromatography. The enzyme solution $(576 \mathrm{mg}$ protein, $20 \mathrm{ml}$ ) was applied to a DEAE-Sepharose CL-6B column equilibrated with Tris-PMSF, and then the enzyme was eluted with a linear concentration gradient of $\mathrm{KCl}$ from 0 to $1.0 \mathrm{M}$ (total volume, $1,000 \mathrm{ml}$ ). Fractions were collected at $6 \mathrm{ml} /$ tube/12 $\mathrm{min}$, and the active fractions (conductivity, $17 \sim 20 \mathrm{m \mho}$ ) were pooled, concentrated with an Amicon PM10 membrane, and then dialyzed against $10 \mathrm{~mm}$ potassium phosphate buffer $(\mathrm{pH} 7.3)$ at $4^{\circ} \mathrm{C}$ overnight.

(4) Hydroxylapatite column chromatography. The dialyzate $(88.3 \mathrm{mg}$ protein, $15.7 \mathrm{ml})$ was applied to a hydroxylapatite column $(2.0 \mathrm{~cm} \times 15 \mathrm{~cm})$ equilibrated with $10 \mathrm{~mm}$ potassium phosphate buffer ( $\mathrm{pH} 7.3$ ), and then the enzyme was eluted with a linear gradient of the buffer $(10 \sim 500 \mathrm{~mm}$, total volume, $150 \mathrm{ml})$. Fractions were collected at a flow rate of $2.5 \mathrm{ml} / \mathrm{tube} / 10 \mathrm{~min}$. The active fractions (conductivity, $27.5 \sim 30 \mathrm{~m} \mho$ ) were combined and concentrated to approximately $2 \mathrm{ml}$ with an Amicon PM10 membrane.

(5) Sephadex G-75 column chromatography. The enzyme solution (21.6 mg protein, $2 \mathrm{ml}$ ) was chromatographed on a Sephadex G-75 column $(1.2 \mathrm{~cm} \times 90 \mathrm{~cm})$ equilibrated with Tris-PMSF at a flow rate of $1.5 \mathrm{ml} /$ tube $/ 15 \mathrm{~min}$. The active fractions (Fr. Nos. 80 95) were pooled, concentrated with an Amicon PM10. membrane, and then dialyzed against $5.0 \mathrm{~mm}$ Tris- $\mathrm{HCl}$ buffer $\left(\mathrm{pH} \mathrm{7.3)}\right.$ at $4^{\circ} \mathrm{C}$ overnight. The final enzyme preparation was divided into small portions and stored at $-20^{\circ} \mathrm{C}$ until use.

Molecular weight determination. Molecular weight (M.W.) determination was performed with a calibrated column of Sephadex G-150 $(1.0 \mathrm{~cm} \times 90 \mathrm{~cm})$ according to the method of Andrews. ${ }^{7)}$ All the proteins were eluted with $5.0 \mathrm{~mm}$ Tris- $\mathrm{HCl}$ buffer ( $\mathrm{pH} 7.5$ ).

Polyacrylamide gel electrophoresis. Polyacrylamide gel electrophoresis in the presence and absence of sodium dodesyl sulfate (SDS) was conducted according to the method of Laemmli. ${ }^{8}$ )

\section{RESULTS}

\section{Purification of glyoxalase II}

The overall purification procedure for glyoxalase II is summarized in Table I. The elution pattern of the enzyme on hydroxylapatite column chromatography is shown in Fig. 1. The enzyme was purified approximately 100 fold from a cell extract with a $20 \%$ activity yield. The purified enzyme was found to be homogeneous on SDS/polyacrylamide gel electrophoresis (Fig. 2B, lane 7).

\section{Molecular weight determination}

By using a calibrated column of Sephadex 
Table I. Summary of Purification of Glyoxalase II

\begin{tabular}{llcccc}
\hline \multicolumn{1}{c}{ Step } & $\begin{array}{c}\text { Total } \\
\text { protein } \\
(\mathrm{mg})\end{array}$ & $\begin{array}{c}\text { Specific } \\
\text { activity } \\
(\mathrm{nmol} / \mathrm{min} / \\
\text { mg-protein) }\end{array}$ & $\begin{array}{c}\text { Total } \\
\text { activity } \\
(\mathrm{nmol} / \mathrm{min})\end{array}$ & $\begin{array}{c}\text { Yield } \\
(\%)\end{array}$ & Fold \\
\hline 1. Cell extract & 5,830 & 13.8 & 80,500 & 100 & 1.00 \\
2. DEAE-cellulose & 2,160 & 43.4 & 93,700 & 116 & 3.14 \\
3. Sephadex G-150 & 576 & 83.5 & 48,200 & 59.9 & 6.05 \\
4. DEAE-Sepharose CL-6B & 88.3 & 340 & 30,000 & 37.3 & 24.6 \\
5. Hydroxylapatite & 21.6 & 1,150 & 24,800 & 30.8 & 83.3 \\
6. Sephadex G-75 & 11.0 & 1,340 & 14,700 & 18.3 & 97.1 \\
\hline
\end{tabular}

The purification procedure was described in detail under MATERIALS AND METHODS.

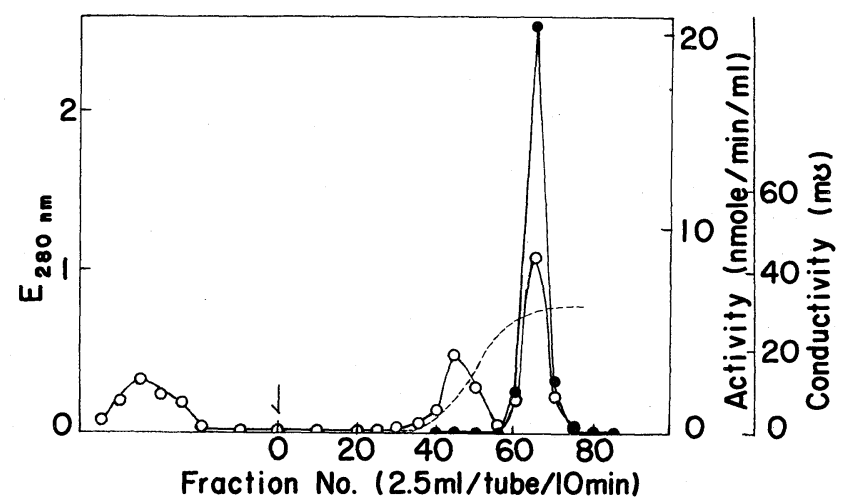

FIG. 1. Elution Pattern of Glyoxalase II on Hydroxylapatite Column Chromatography.

The detailed chromatographic conditions were given under MATERIALS AND METHODS. Elution of the enzyme was started at the position indicated by an arrow. - $\bigcirc-$, absorbancy at $280 \mathrm{~nm}$; - - - , activity; ------, conductivity of eluates.

G-150, a molecular weight (M.W.) of 19,000 was obtained for the purified glyoxalase II (Fig. 2A). The enzyme treated with SDS in the presence of dithiothreitol also migrated as a single protein band of a M.W. $=19,000$ (Fig. 2B, lane 7).

\section{Effect of $\mathrm{pH}$ and temperature}

The enzyme was remarkably active at low pH (pH 3 4) (Fig. 3A). Above pH 9.0, the activity was rapidly lost. The enzyme was stable in the broad $\mathrm{pH}$ range of $4 \sim 8$ (Fig. 3B).

The enzyme was most active at $45^{\circ} \mathrm{C}$ in $10 \mathrm{~mm}$ Tris- $\mathrm{HCl}$ buffer ( $\mathrm{pH}$ 7.0) (data not shown). A $50 \%$ activity loss occurred on incubation of the enzyme in $10 \mathrm{~mm}$ Tris- $\mathrm{HCl}$ buffer (pH 7.0) at $40^{\circ} \mathrm{C}$ for $14 \mathrm{~min}$, and at $50^{\circ} \mathrm{C}$ for $2 \mathrm{~min}$ (Fig. 4). The stability of the enzyme in $0.001 \mathrm{~N} \mathrm{HCl}$ at various temperatures was examined (Fig. 4). The enzyme was stable even in $0.001 \mathrm{~N} \mathrm{HCl}$ at $40^{\circ} \mathrm{C}$ for at least $15 \mathrm{~min}$.

\section{Inhibitors}

The effects of several metal ions on the glyoxalase II activity were investigated (Table II). The enzyme was neither activated nor inhibited by the divalent metal ions tested $\left(\mathrm{Mn}^{2+}, \mathrm{Mg}^{2+}, \mathrm{Ni}^{2+}, \mathrm{Co}^{2+}, \mathrm{Ca}^{2+} ; 5.0 \mathrm{mM}\right.$ each). Metal chelators such as ethylenediaminetetraacetate $(2.5 \mathrm{~mm})$ and 8-hydroxyquinoline $(2.5 \mathrm{~mm})$ also had no effect. Reducing agents inhibited the activity of the enzyme. The inhibition was $60 \%$ with dithiothreitol at $1.25 \mathrm{~mm}$, and $43 \%$ with glutathione at $8.0 \mathrm{~mm}$. p-Chloromercuribenzoic acid and $\mathrm{HgCl}_{2}$ completely inhibited the activity at 

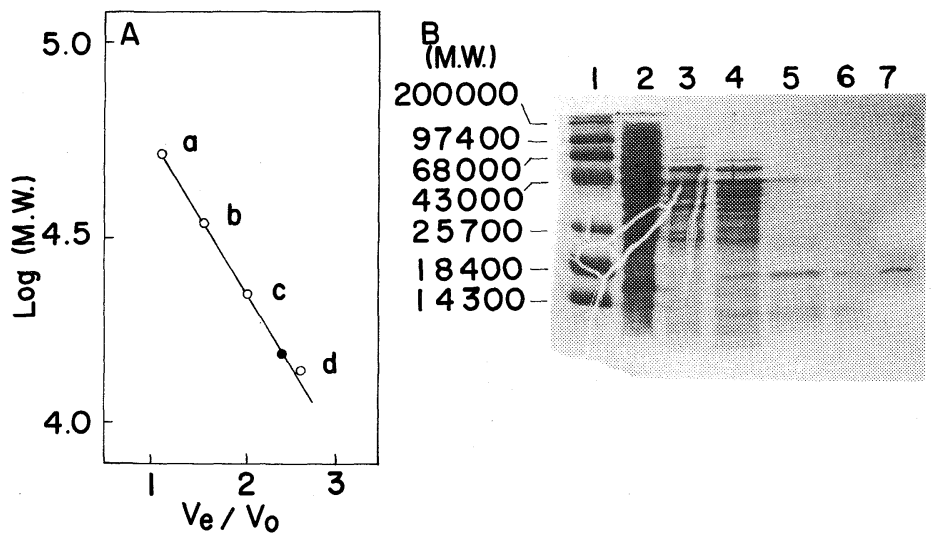

FIG. 2. Molecular Weight Determination of Glyoxalase II.

A: Sephadex G-150 column chromatography of glyoxalase II. Ve (elution volume)/Vo (void volume) was plotted versus Log [M.W.]. The position of glyoxalase II is shown by a closed circle. The standard proteins used were: a, pyruvate kinase $($ M.W. $=57,000)$; b, glyceraldehyde-3-phosphate dehydrogenase (M.W. =36,000); c, trypsin (M.W. $=23,000)$; and d, lysozyme (M.W.=14,300).

B: SDS/polyacrylamide gel electrophoresis of samples at various purification steps. Samples at various purification steps were subjected to SDS $(0.1 \%)$ polyacrylamide $(12.5 \%$ ) gel electrophoresis (lanes $2 \sim 7)$. The samples and protein amounts applied were: lane 2, cell extract $(80 \mu \mathrm{g})$; lane 3 , after DEAE-cellulose column chromatography ( $40 \mu \mathrm{g}$ ); lane 4, after Sephadex G-150 column chromatography (40 $\mu \mathrm{g})$; lane 5, after DEAESepharose CL-6B column chromatography $(20 \mu \mathrm{g})$; lane 6, after Hydroxylapatite column chromatography $(5 \mu \mathrm{g})$; and lane 7, after Sephadex G-75 column chromatography (5 $\mu \mathrm{g})$. The standard proteins used in Lane 1 were: myosin (H-chain) (M.W.=200,000); phosphorylase B (M.W.=97,400); bovine serum albumin $(M . W .=68,000) ; \quad$ ovalbumin $\quad(M . W .=43,000) ; \quad \alpha$-chymotrypsinogen $\quad(M . W .=25,700) ; \quad \beta$-lactoglobulin (M.W. =18,400); and lysozyme (M.W. =14,300).

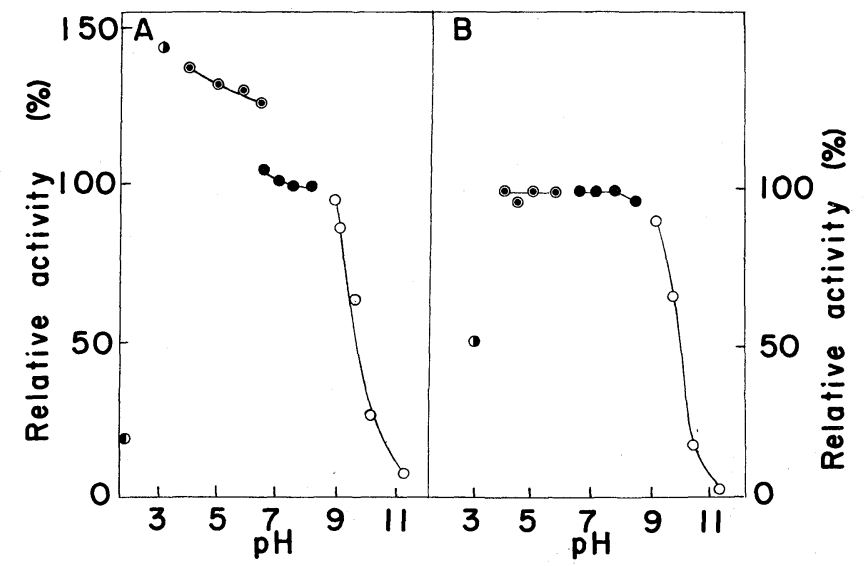

FIG. 3. Effect of pH on Activity (A) and Stability (B) of Glyoxalase II.

For determination of the optimal $\mathrm{pH}$ for activity, the reaction was carried out at various $\mathrm{pHs}$, the activity seen at pH 7.0 (Tris- $\mathrm{HCl}$ buffer) being taken as $100 \%$. The buffers used were: $-\odot-$, acetate buffer; $-\bigcirc-$, Tris$\mathrm{HCl}$ buffer; - $\mathrm{O}-$, glycine-KOH buffer;, $0.001 \mathrm{~N} \mathrm{HCl}$; and $\boldsymbol{O}, 0.01 \mathrm{~N} \mathrm{HCl}$. For determination of the stability of the enzyme, $5.0 \mu \mathrm{g}$ of enzyme was incubated at $40^{\circ} \mathrm{C}$ for $5 \mathrm{~min}$ at various pHs, and then residual activity was assayed under the standard conditions. The buffers used were: $-\odot-$, acetate buffer;

Tris- $\mathrm{HCl}$ buffer; - $\mathrm{O}-$, glycine- $\mathrm{KOH}$ buffer; and $0.001 \mathrm{~N} \mathrm{HCl}$. The activity at $\mathrm{pH} 7.0$ was taken as $100 \%$. 


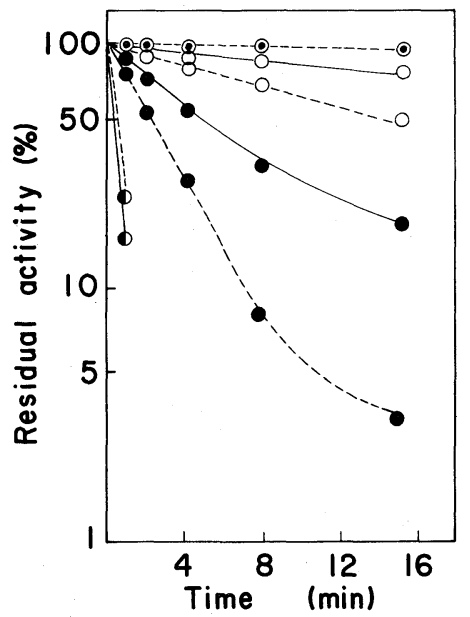

FIG. 4. Effect of Temperature on Stability of Glyoxalase II.

The enzyme $(5.0 \mu \mathrm{g})$ was incubated in $10 \mathrm{~mm}$ Tris- $\mathrm{HCl}$ buffer (pH 7.0) (-----) or $0.001 \mathrm{~N} \mathrm{HCl} \mathrm{(-)} \mathrm{at} \mathrm{various}$ temperatures $\left(\odot, 25^{\circ} \mathrm{C} ; \bigcirc, 40^{\circ} \mathrm{C} ; \bigcirc, 50^{\circ} \mathrm{C}\right.$; and $\left.\mathrm{D}, 60^{\circ} \mathrm{C}\right)$ for several minutes, and then residual activities were assayed under the standard conditions.

$0.3 \mathrm{~mm}$ and $0.5 \mathrm{~mm}$, respectively. Formaldehyde, acetaldehyde, glycoaldehyde and pyruvealdehyde had no effects at $10 \mathrm{~mm}$ (data not shown). The effect of hemimercaptal, a non-enzymatic condensation product of methylgyoxal and glutathione, was studied (Table III). When both of reduced glutathione and methylglyoxal were present, marked inhibition of glyoxalase II activity was observed at the concentration at which neither alone was so inhibitory, except for in the case of glutathione at $8.0 \mathrm{~mm}$. The inhibition increases with increasing concentration of either reduced glutathione or methylglyoxal.

\section{Substrate specificity}

The enzyme specifically hydrolyzed $S$ lactoylglutathione. $S$-Acetylglutathione, $S$ methylglutathione, $S$-butylglutathione, $S$ - $(n$ propyl)glutathione and $S$-hexylglutathione were not hydrolyzed by the enzyme. The substrate ( $S$-lactoylglutathione) saturation curve for the glyoxalase II reaction is shown in Fig. $5 \mathrm{~A}$. When the results in Fig. 5A were plotted in a double reciprocal form, a parabolic relationship was observed (data not shown). However,
Table II. EfFects of Various Chemicals on GlyoXalase II ACTIVITY

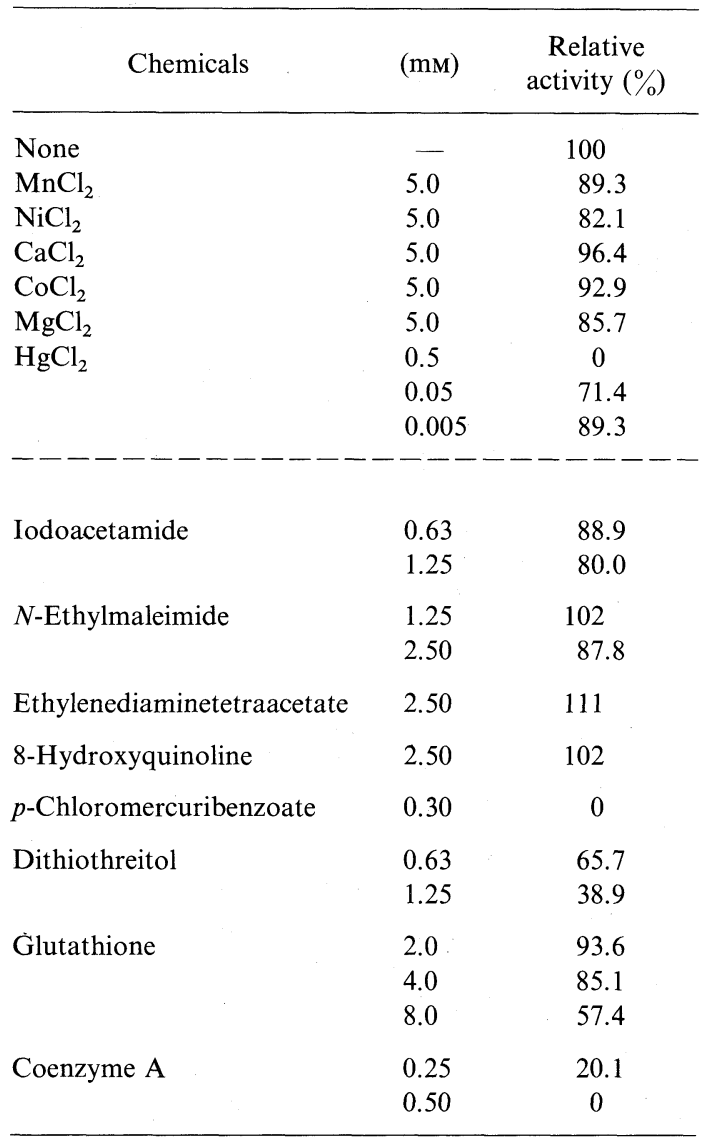

Activities were determined under the standard conditions in the presence of various chemicals at the concentrations indicated.

this could be converted into a linear relationship by plotting the reciprocal of the square of the substrate concentration (Fig. 5B), and the $K m$ of the enzyme for $S$-lactoylglutathione was estimated to be $7 \times 10^{-6} \mathrm{M}$. The reaction products of glyoxalase II reaction were determined enzymatically to be lactate and glutathione with lactate dehydrogenase and glutathione reductase (data not shown).

\section{DISCUSSION}

Glyoxalase II is one of the thiol esterases and catalyzes the hydrolysis of glutathione thiol esters formed from $\alpha$-keto-aldehydes (glyoxal, methylglyoxal and phenylgyloxal) and 
Table III. Inhibition of Glyoxalase II Activity BY HEMIMERCAPTAL

\begin{tabular}{|c|c|c|}
\hline Assay conditions & $\begin{array}{c}\text { Relative } \\
\text { activity } \\
(\%)\end{array}$ & $\begin{array}{c}\text { Inhibition } \\
(\%)\end{array}$ \\
\hline Control (No addition) & 100 & 0 \\
\hline Control+ $5.0 \mathrm{~mm} \mathrm{MG}$ & 85.1 & 14.9 \\
\hline$+10 \mathrm{~mm} \mathrm{MG}$ & 80.8 & 19.2 \\
\hline$+20 \mathrm{~mm} \mathrm{MG}$ & 76.6 & 23.4 \\
\hline Control+ $2.0 \mathrm{~mm} \mathrm{GSH}$ & 93.6 & 6.4 \\
\hline$+4.0 \mathrm{~mm} \mathrm{GSH}$ & 85.1 & 14.9 \\
\hline$+8.0 \mathrm{~mm}$ GSH & 57.4 & 42.6 \\
\hline $\begin{array}{r}\text { Control }+10 \mathrm{~mm} \mathrm{MG} \\
2.0 \mathrm{~mm} \mathrm{GSH}\end{array}$ & 21.3 & 78.7 \\
\hline $\begin{array}{r}+10 \mathrm{~mm} \mathrm{MG} \\
4.0 \mathrm{~mm} \mathrm{GSH}\end{array}$ & 12.8 & 87.2 \\
\hline $\begin{array}{r}+10 \mathrm{~mm} \mathrm{MG} \\
8.0 \mathrm{~mm} \mathrm{GSH}\end{array}$ & 1.3 & 98.7 \\
\hline $\begin{aligned} \text { Control }+ & 4.0 \mathrm{~mm} \mathrm{GSH} \\
& 5.0 \mathrm{~mm} \mathrm{MG}\end{aligned}$ & 10.2 & 89.8 \\
\hline $\begin{array}{c}+4.0 \mathrm{~mm} \text { GSH } \\
10 \mathrm{~mm} \mathrm{MG}\end{array}$ & 0.8 & 99.2 \\
\hline
\end{tabular}

Activities were determined under the standard conditions in the presence of methylglyoxal (MG) or glutathione (GSH), or both.

glutathione through the action of glyoxalase I (Eq. 1). Glyoxalase II has been purified from beef liver ${ }^{1)}$ and human liver, ${ }^{1)}$ and the properties of the latter enzyme were determined in detail. The yeast glyoxalase II presented here was closely similar to the human liver enzyme in molecular weight (yeast enzyme M.W. =19,000; human liver enzyme M.W. $=22,000$ ), sensitivity to inhibitors (hemimercaptal and reducing agents such as glutathione) and the $\mathrm{pH}$-activity profile.

The severe inhibition (feedforward inhibition) of glyoxalase II by hemimercaptal, a substrate for glyoxalase $\mathrm{I}$, is of physiological significance in regulation of the level of $S$ lactoylglutathione in yeast cells. The yeast cells used showed no detectable $S$-lactoylglutathione-hydrolyzing activity other than that of glyoxalase II (unpublished data). So, the inhibition of glyoxalase II by hemimercaptal inevitably leads to accumulation of $S$ -
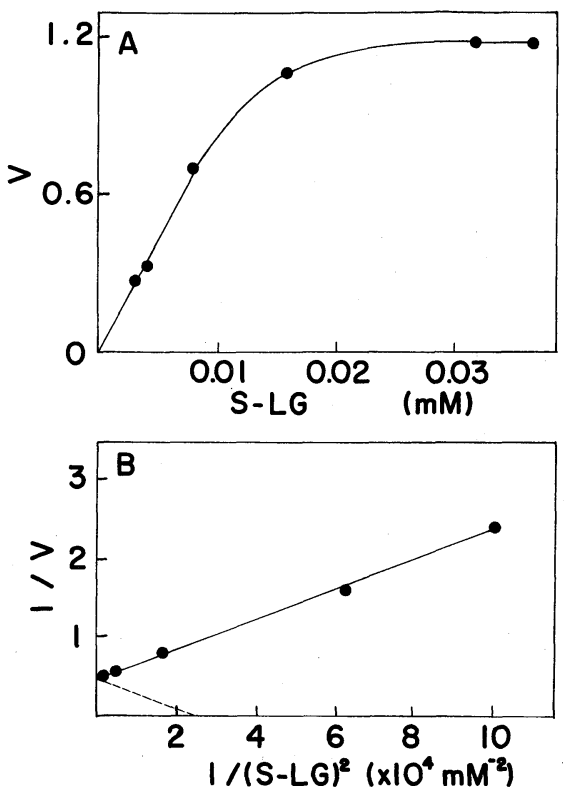

FIG. 5. Relationship between Reaction Velocity and Substrate Concentrations.

A: Saturation curve for the glyoxalase II reaction. The reaction was carried out under the standard conditions except that the substrate ( $S$-LG: $S$-lactoylglutathione) concentration was varied and the velocity $(\mu \mathrm{mol} / \mathrm{min} / \mathrm{mg}$ protein) was plotted as a function of $S$-LG concentration. B: Double reciprocal plots of the velocity (arbitrary unit) versus the square of the $S$-LG concentration.

lactoylglutathione in cells. A similar proposal that the function of glyoxalase I and II is to regulate the cellular level of $S$-lactoylglutathione, has been made by Gillespie. ${ }^{9)}$ These observations indicate an important function of $S$-lactoylglutathione in cellular metabolism.

In mammalian cells, $S$-lactoylglutathione potentiates histamine release from human leucocytes ${ }^{10)}$ and modulates microtubule assembly in vitro. ${ }^{11)}$ Evidence has also accumulated as to the function of $S$-lactoylglutathione in modulating immune and inflammatory responces. The 12-O-tetradecanoylphorbol-13acetate, with the ability to induce tumors in mouse skin, has been shown to increase the level of $S$-lactoylglutathione in cells by increasing the glyoxalase I activity and decreasing the glyoxalase II activity. ${ }^{9)}$ The increased $S$ lactoylglutathione level (i.e. a decreased level 
Table IV. Properties of the EnZyme Responsible for Methylglyoxal Metabolism in Yeast

\begin{tabular}{|c|c|c|c|c|c|}
\hline Properties & $\begin{array}{l}\text { Methylglyoxal } \\
\text { synthase }\end{array}$ & $\begin{array}{c}\text { Glyoxalase } \\
\text { I }\end{array}$ & $\begin{array}{l}\text { Glyoxalase } \\
\text { II }\end{array}$ & $\begin{array}{l}\text { Methylglyoxal } \\
\text { reductase }\end{array}$ & $\begin{array}{l}\text { Lactaldehyde } \\
\text { dehydrogenase }\end{array}$ \\
\hline M.W. & 26,000 & 32,000 & 19,000 & $\begin{array}{c}43,000 \\
\text { (Glycoprotein) }\end{array}$ & 40,000 \\
\hline $\begin{array}{l}\text { Substrate } \\
\text { specificity }\end{array}$ & $\begin{array}{l}\text { Specific to } \\
\text { DHAP }\end{array}$ & $\mathrm{G}, \mathrm{MG}, \mathrm{PhG}$ & $\begin{array}{l}\text { Specific to } \\
S \text {-LG }\end{array}$ & $\begin{array}{l}\mathrm{G}, \mathrm{MG}, \mathrm{PhG} \\
\text { Specific to } \\
\text { NADPH }\end{array}$ & $\begin{array}{c}\text { Specific to } \\
\text { L-LAL and NAD }\end{array}$ \\
\hline$K m$ & $\begin{array}{c}3.0 \mathrm{mM} \\
\text { (for DHAP) }\end{array}$ & $\begin{array}{c}0.15 \mathrm{mM} \\
\text { (for } \mathrm{MG} \text { ) } \\
0.10 \mathrm{mM} \\
\text { (for } \mathrm{PhG} \text { ) }\end{array}$ & $\begin{array}{c}7.0 \mu \mathrm{M} \\
\text { (for } \mathrm{S}-\mathrm{LG} \text { ) }\end{array}$ & $\begin{array}{c}5.88 \mathrm{mM} \\
\text { (for } \mathrm{MG} \text { ) } \\
1.54 \mathrm{mM} \\
\text { (for } \mathrm{PhG)} \\
0.20 \mathrm{mM} \\
\text { (for } \mathrm{NADPH} \text { ) }\end{array}$ & $\begin{array}{c}10 \mathrm{~mm} \\
\text { (for } \mathrm{L}-\mathrm{LAL} \text { ) } \\
2.9 \mathrm{mM} \\
\text { (for NAD) }\end{array}$ \\
\hline Optimal pH & $9 \sim 10$ & $6 \sim 8$ & $3 \sim 4$ & 7.0 & 6.5 \\
\hline Inhibitors & $\begin{array}{l}\text { 3-PGA, PEP, GSH, } \\
\text { L-cysteine }\end{array}$ & $\begin{array}{c}\text { EDTA } \\
\mathrm{Zn}^{2+}\end{array}$ & $\begin{array}{c}\text { GSH } \\
\text { Coenzyme A } \\
\text { Hemimercaptal }\end{array}$ & $\begin{array}{c}\text { NADP } \\
(K i=70 \mathrm{nM})\end{array}$ & \\
\hline Activators & & $\begin{array}{c}\text { Polyamines } \\
\mathrm{Fe}^{2+}\end{array}$ & & GSH, DTT, 2-ME & $\begin{array}{c}\text { Halide ion } \\
\left(\mathrm{Cl}^{-}, \mathrm{I}^{-}, \mathrm{Br}^{-}\right)\end{array}$ \\
\hline
\end{tabular}

Abbreviations: DHAP, dihydroxyacetonephosphate; 3-PGA, glyceraldehyde-3-phosphate; PEP, phosphoenolpyruvate; GSH, reduced glutathione; G, glyoxal; MG, methylglyoxal; PhG, phenylglyoxal; $S$-LG, $S$-lactoylglutathione; DTT, dithiothreitol; 2-ME, 2-mercaptoethanol; L-LAL, L-lactaldehyde; EDTA, ethylenediaminetetraacetate.

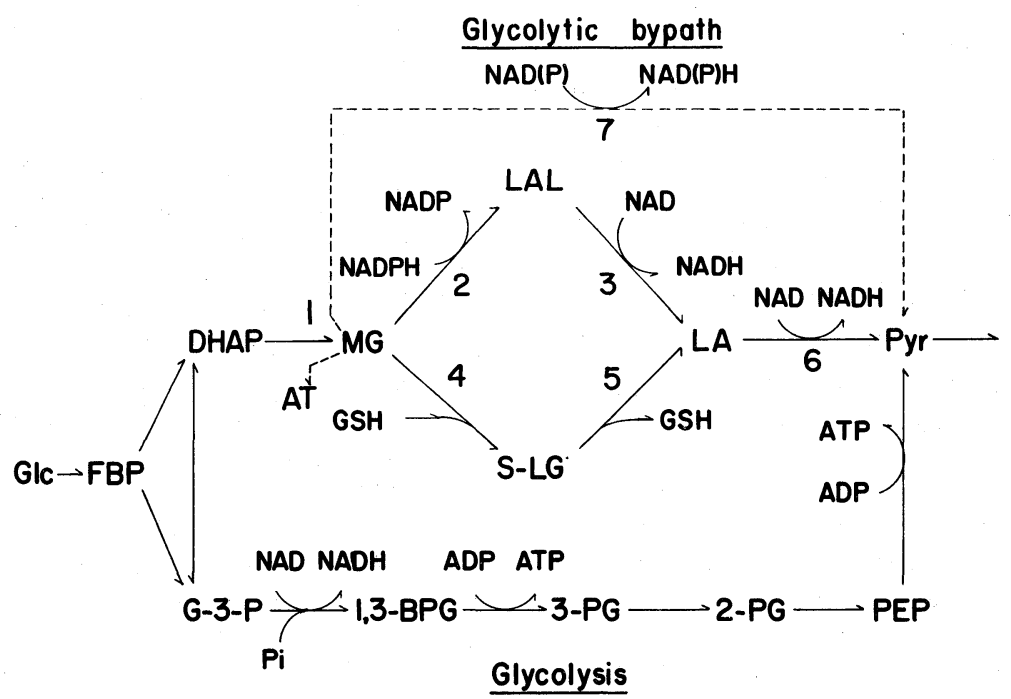

FIG. 6. Tentative Pathway for Methylglyoxal Metabolism (Glycolytic Bypath) in S. cerevisiae.

The abbreviations used for intermediates are: Glc, glucose; FBP, fructose-1,6-bisphosphate; DHAP, dihydroxyacetonephosphate; G-3-P, glyceraldehyde-3-phosphate; 1,3-BPG, 1,3-bisphosphoglycerate; 3-PG, 3-phosphoglycerate; 2-PG, 2-phosphoglycerate; PEP, phosphoenolpyruvate; MG, methylglyoxal; Llactaldehyde; $S$-LG, $S$-lactoylglutathione; AT, acetol (1-hydroxy-2-propanone); LA, lactic acid; Pyr, pyruvate; and GSH, reduced glutathione. Enzymes: 1, methylglyoxal synthase; 2, methylglyoxal reductase; 3, Llactaldehyde dehydrogenase; 4, glyoxalase I; 5, glyoxalase II; and 6, lactate dehydrogenase. The activity converting MG to pyruvate or AT, of which the pathways are shown by dotted lines was not detected in our yeast strain. 
of glyoxalase II activity) is related to the tumor promoting properties of the compound. In fact, Jerzykowsky et al. ${ }^{12,13)}$ reported that no glyoxalase II activity was detected in approximately two-thirds of the tumors studied, while in the remaining one-third it was low compared to the activity in normal tissues. However, no data have been reported so far as to the function of $S$-lactoylglutathione in microbial cells.

Taking into account the similar properties of the glyoxalase II in yeast and mammalian cells, yeast cells may constitute a rapid and sensitive system for the elucidation of the functions of $S$-lactoylglutathione. For studies in this direction, we have already purified the enzymes responsible for the methylglyoxal metabolism in yeast. These enzymes are methylglyoxal synthase [EC 4.2.99.11] ${ }^{14)}$, methylglyoxal reductase, ${ }^{5)}$ lactaldehyde dehydrogenase $^{15)}$ and glyoxalase II presented here. The properties of these enzymes are summarized in Table IV. Based on the results of product analyses of the reactions catalyzed by these enzymes, we established, for the first time, the pathway for methylglyoxal metabolism (Glycolytic bypath; Fig. 6). Our preliminary data $^{16)}$ on the enzyme activities involved in the bypath indicated that the activity converting methylglyoxal to lactate via lactaldehyde was high in growing cells and low in non-growing cells. On the other hand, the activity converting methylglyoxal to lactate via $S$-lactoylglutathione was low in growing cells and high in non-growing cells. We are now investigating the physiological functions of the two routes leading from methylglyoxal to lactate via lactaldehyde or $S$-lactoylglutathione.
The functions of intermediates (methylglyoxal, hemimercaptal, $S$-lactoylglutathione and lactaldehyde) in yeast cell division are also being investigated.

Acknowledgments. We thank Dr. M. Sakaguchi for his continuous help in this work. We also thank Ms. N. Okamoto for her technical assistance. This study was supported in part by a Grant-in-Aid for Scientific Research (No. 60560114) from the Ministry of Education, Science and Culture of Japan.

\section{REFERENCES}

1) E. Racker, J. Biol. Chem., 190, 685 (1951).

2) E. Marmstal, A.-C. Aronsson and B. Mannervik, Biochem. J., 183, 23 (1979).

3) L. Uotila, Biochemistry, 12, 3944 (1973).

4) W. W. Kielley and L. B. Bradley, J. Biol. Chem., 206, 327 (1954).

5) K. Murata, Y. Fukuda, K. Watanabe, M. Shimosaka, T. Saikusa and A. Kimura, Eur. J. Biochem., 151, 631 (1985).

6) O. H. Lowry, N. J. Rosebrough, A. L. Farr and R. J. Randall, J. Biol. Chem., 193, 265 (1951).

7) P. Andrews, Biochem. J., 96, 595 (1969).

8) U. K. Laemmli, Nature, 227, 135 (1979).

9) E. Gillespie, Biochem. Biophys. Res. Commun., 98, 463 (1981).

10) E. Gillespie, Nature, 227, 135 (1979).

11) E. Gillespie, Fedn. Proc., 34, 541 (1975).

12) T. Jerzykowski, R. Winter, W. Matsuzewski and Z. Szeziurek, Experientia, 31, 32 (1975).

13) R. Winter, K. Piskorska and T. Jerzykowski, Neoplasma, 25, 465 (1978).

14) K. Murata, Y. Fukuda, K. Watanabe, T. Saikusa, M. Shimosaka and A. Kimura, Biochem. Biophys. Res. Commun., 131, 190 (1985).

15) Y. Inoue, K. Murata, K. Watanabe, T. Saikusa, M. Shimosaka and A. Kimura, Eur. J. Biochem., in press (1985).

16) K. Murata, Y. Inoue, K. Watanabe, Y. Fukuda, T. Saikusa, M. Shimosaka and A. Kimura, J. Ferment. Technol., in press (1985). 